Article

\title{
Insight into the Intermolecular Interaction and Free Radical Polymerizability of Methacrylates in Supercritical Carbon Dioxide
}

\author{
Rui-Qing Li ${ }^{1,+}{ }^{\mathbb{D}}$, Ming-Xi Wang ${ }^{1,2,+}$, Qi-Yu Zhang ${ }^{1}$, Jian-Gang Chen $\left.{ }^{1, *} \mathbb{(}\right)$, Kuan Wang ${ }^{2}$, \\ Xiao-Yong Zhang ${ }^{1}$, Shukun Shen ${ }^{3}$, Zhao-Tie Liu ${ }^{1,2, *}$, Zhong-Wen Liu ${ }^{1}$ and Jinqiang Jiang ${ }^{1}$ \\ 1 Key Laboratory of Applied Surface and Colloid Chemistry, Ministry of Education and School of Chemistry \& \\ Chemical Engineering, Shaanxi Normal University, Xi'an 710119, China; liruiqing@snnu.edu.cn (R.-Q.L.); \\ wangmingxi@snnu.edu.cn (M.-X.W.); zhangqiyu@snnu.edu.cn (Q.-Y.Z.); \\ zhangxiaoyong@snnu.edu.cn (X.-Y.Z.); zwliu@snnu.edu.cn (Z.-W.L.); jiangjq@snnu.edu.cn (J.J.) \\ 2 College of Chemistry and Chemical Engineering, Shaanxi University of Science \& Technology, Xi'an 710021, \\ China; wangkuan@sust.edu.cn \\ 3 School of Materials Science \& Engineering, Shaanxi Normal University, Xi'an 710119, China; \\ shukun_shen@snnu.edu.cn \\ * Correspondence: jgchen@snnu.edu.cn (J.-G.C.); ztliu@snnu.edu.cn (Z.-T.L.); \\ Tel.: +86-29-81530803 (J.-G.C.); +86-29-81530802 (Z.-T.L.) \\ + These authors contributed equally to this work.
}

Received: 2 December 2019; Accepted: 16 December 2019; Published: 2 January 2020

check for updates

\begin{abstract}
High pressure in situ Fourier transfer infrared/near infrared technology (HP FTIR/NIR) along with theoretical calculation of density functional theory (DFT) method was employed. The solvation behaviors and the free radical homopolymerization of methyl methacrylate (MMA), methacrylate acid (MAA), trifluoromethyl methacrylate (MTFMA) and trifluoromethyl methacrylate acid (TFMAA) in $\mathrm{scCO}_{2}$ were systematically investigated. Interestingly, the previously proposed mechanism of intermolecular-interaction dynamically-induced solvation effect (IDISE) of monomer in $\mathrm{scCO}_{2}$ is expected to be well verified/corroborated in view that the predicted solubility order of the monomers in $\mathrm{scCO}_{2}$ via DFT calculation is ideally consistent with that observed via HP FTIR/NIR. It is shown that MMA and MAA can be easily polymerized, while the free radical polymerizability of MTFMA is considerably poor and TFMAA cannot be polymerized via the free radical initiators. The $\alpha$ trifluoromethyl group $\left(-\mathrm{CF}_{3}\right)$ may effectively enhance the intermolecular hydrogen bonding and restrain the diffusion of the monomer in $\mathrm{scCO}_{2}$. More importantly, the strong electron-withdrawing inductive effect of $-\mathrm{CF}_{3}$ to $\mathrm{C}=\mathrm{C}$ may distinctly decrease the atomic charge of the carbon atom in the methylene $\left(=\mathrm{CH}_{2}\right)$. These two factors are believed to be predominantly responsible for the significant decline of the free radical polymerizability of MTFMA and the other alkyl 2-trifluoromethacrylates in $\mathrm{ScCO}_{2}$.
\end{abstract}

Keywords: intermolecular interaction; free radical polymerization; methacrylate monomer; supercritical carbon dioxide $\left(\mathrm{scCO}_{2}\right)$; theoretical calculation

\section{Introduction}

Owing to the unique structure and superior performances, methacrylate-based monomers and polymers have attracted much attentions [1-3], especially for the fluorinated ones. For example, it was reported that fluorinated methacrylate polymers have excellent surface properties, impressive optical performances [4,5] and thus are extensively applied in the fields of ice-phobic coatings, functional thin film, medical materials, optical devices/fiber and nanocomposites [6-10]. Among the 
methacrylates, alkyl 2-trifluoromethacrylate(s) is suggested to be less active since a strong inductive electron-withdrawing trifluoromethyl group $\left(-\mathrm{CF}_{3}\right)$ is connected to the $\alpha$ position [11]. Thus, the study on the polymerization of such monomers is of special theoretical significance, besides the potential application prospects of the corresponding polymers. Dickey et al. claimed that 2-trifluoromethyl methacrylate (MTFMA) could be polymerized by heat in the existence of the free radical initiator like benzoyl peroxide (BPO) [12]. However, no structural detail of the obtained polymer was provided. Other researchers attempted to repeat the claim and further explored the homopolymerization of trifluoromethacrylate(s) via radical initiators but most of them failed [11]. Ito et al. reported that MTFMA can be anionically homopolymerized and free radical copolymerized with methyl methacrylate (MMA) but cannot be homopolymerized via radical initiation due to the low electron density on the double bond [11]. So far there are no consistent results or explanations on the free radical polymerizability of alkyl 2-trifluoromethacrylates, which seriously restrict the research and application of such category of monomers. Moreover, the successful free radical homopolymerization of such monomers is rarely reported. The mechanistic understanding of the free radical polymerizability of such monomers is highly needed.

Recently, supercritical carbon dioxide $\left(\mathrm{scCO}_{2}\right)$ is increasingly accepted as the most promising medium for the synthesis of fluorinated polymers because of its distinct advantages over traditional solvents. Besides its high diffusivity, low viscosity, easy accessibility of critical conditions and continuously tunable physical properties, the superiority of the inertness to effectively restraint the chain transfer reactions as well as the high solvability for many fluorinated monomers/polymers [13-16], is particularly suitable for the polymerization of fluorinated monomers. A variety of fluorinated monomers have been successfully polymerized in $\mathrm{scCO}_{2}$ till now [17-19], however, in which the alkyl 2-trifluoromethacrylates were not included. We found that the solvation behaviors of the fluorinated monomer/polymer in $\mathrm{scCO}_{2}$ are dominated by the interactions among the polymerization system [20]. It is also reported that the solubility of fluorinated polymers in $\mathrm{scCO}_{2}$ is much bigger than that of non-fluorinated ones partly due to the special attraction between the $\mathrm{F}$ atoms $(\mathrm{C}-\mathrm{F}$ bond) and $\mathrm{CO}_{2}$. Moreover, the fluorine repulsion and the resulted decrease in the strength of the polymer-polymer interactions is believed to play a key role to the enhanced solubility of the fluorinated polymers in $\mathrm{scCO}_{2}[13,20]$. While based on the experimental results and the theoretical calculations in perfluorooctanoic acid (FOA) $+\mathrm{scCO}_{2}$ system, it is reported that the interaction between the carbonyl group and $\mathrm{CO}_{2}$ may contribute more than that between $\mathrm{C}-\mathrm{F}$ and $\mathrm{CO}_{2}$ to the attraction with $\mathrm{CO}_{2}$ [21]. So far high pressure in situ Fourier transform infrared/near infrared (HP FTIR/NIR) has been proved to be one of the most effective techniques to investigate the intermolecular interactions as well as the thermodynamic and kinetic properties in the $\mathrm{scCO}_{2}$ system $[20,22]$. Besides, ab initio/theoretical calculation is believed to be a most promising complement method to understand the interactions in $\mathrm{scCO}_{2}$ system [23-25]. Therefore, the interactions between alkyl 2-trifluoromethacrylate and $\mathrm{CO}_{2}$ should be revealed in order that the solvation behaviors may be better understood and the polymerization of such monomers in $\mathrm{scCO}_{2}$ may be successfully performed.

In the present work, a set of patented HP FTIR/NIR system was intentionally employed [26,27], via which the solvation behaviors as well as the free radical homopolymerization of MTFMA, MAA, MMA and TFMAA in $\mathrm{scCO}_{2}$ were in situ monitored. Besides the HP FTIR/NIR technology, the theoretical calculation of DFT method was also used so as to discern the intermolecular interactions in monomer + $\mathrm{CO}_{2}$ system, to reveal the homopolymerization activity of the monomers in $\mathrm{scCO}_{2}$ and to understand the special contribution of $-\mathrm{CF}_{3}$ to the free radical polymerizability of MTFMA in $\mathrm{scCO}_{2}$. The structures of the monomers were shown in Scheme 1. 
<smiles>CC=CC(=O)OC</smiles><smiles>COC(=O)/C=C(/C)C(=O)OC</smiles>

MTFMA<smiles>CC=C(C)C(=O)O</smiles><smiles>O=C(O)/C=C\C(F)(F)F</smiles>

TFMAA

Scheme 1. Structure of model monomers used.

\section{Experimental Section}

\subsection{Materials}

2,2,2-Trifluoromethyl methacrylate acid (TFMAA, 98\%, obtained from Xi'an Modern Chemistry Research Institute, China) and 2,2,2-Trifluoromethyl methacrylate (MTFMA, 97\%, synthesized based on the reported method [28]) were purified by passing through a neutral alumina column twice to eliminate the residual inhibitor. Methyl methacrylate (MMA) and methacrylate acid (MAA) obtained as analytical purity, were distilled under vacuum, then passing through a neutral alumina column prior to use. Benzoyl peroxide (BPO, 97\%) and azobis(isobutyronitrile) (AIBN, 98\%) were recrystallized twice from methanol, dried under vacuum at $20{ }^{\circ} \mathrm{C}$ and stored at $0{ }^{\circ} \mathrm{C}$ prior to use. $\mathrm{CO}_{2}(99.999 \%)$ and $\mathrm{N}_{2}(99.99 \%)$ were used as received.

\subsection{Apparatus}

High pressure in situ FTIR/NIR experiments were performed using a PerkinElmer Spectrum 400 FTIR/NIR spectrometer supported by Spectrum Software (V 6.3.5, PerkinElmer, Bucks, UK) for data acquisition and processing. The spectrometer was intentionally modified either by replacing the standard sample accessories with a set of specially designed fiber sensor in attenuated total reflection (ATR) mode as was described in our previous work [21,29] or by integrating with a $50.0 \mathrm{~mL}$ stainless steel view cell to construct a high-pressure trans FTNIR in situ monitoring system [22]. The view cell was equipped with two sapphire windows, facilitating the in-line FTNIR spectroscopic monitoring of the phase behaviors during the polymerization process. ATR-FTIR spectra were recorded over a wavenumber range of $4000-600 \mathrm{~cm}^{-1}$ for the solvation behaviors of the methacrylate monomers in $\mathrm{scCO}_{2}$. The transmission FTNIR spectra were recorded over a wavenumber range of $7000-5500 \mathrm{~cm}^{-1}$ for the polymerization of every methacrylate in $\mathrm{scCO}_{2}$. Twenty scans were taken in every FTIR/FTNIR spectrum with a resolution of $2 \mathrm{~cm}^{-1}$.

\subsection{Solvation Process and Phase Behaviors of the Monomers in $\mathrm{CO}_{2}$}

The solvation process of monomers in gaseous and supercritical $\mathrm{CO}_{2}$ was monitored by using the high-pressure in situ ATR-FTIR monitoring system, following the similar procedure in our previous work [21,29]. The view cell was heated to the target temperature $\left(60^{\circ} \mathrm{C}\right)$ and then purged with $\mathrm{N}_{2}$ and degassed by a vacuum pump alternately for at least three times to eliminate the possible residuals in the system, then charged with a certain amount of the monomer $(10 \mathrm{~mL})$ via a special syringe and stirred at a speed of around $300 \mathrm{rpm} . \mathrm{CO}_{2}$ was introduced into the view cell in a stepwise fashion to solvate the previously added monomer. The FTIR spectra of the monomer were collected throughout the whole solvation process from 0 to $38.00 \mathrm{MPa}$ at specified pressure intervals while stirring continued. At every selected pressure, the system was stirred for about five minutes until two identical FTIR spectra were obtained. The phase behaviors of the monomer $+\mathrm{CO}_{2}$ system were directly observed through the sapphire windows during the solvation process. 


\subsection{Free Radical Homopolymerization of the Monomers in $\mathrm{scCO}_{2}$}

The free radical homopolymerization of the monomers in $\mathrm{scCO}_{2}$ was studied via the high-pressure FT-NIR monitoring system. The view cell was preheated to the target temperature $\left(60^{\circ} \mathrm{C}\right)$ and purged with $\mathrm{N}_{2}$ and degassed by a vacuum pump alternately for at least three times to eliminate the impurities in the system. Then the view cell was charged with a certain amount of the monomer (approximately $0.05 \mathrm{~mol}$ ) by using a special syringe, stirred at a speed of around $300 \mathrm{rpm}$ and filled with pressurized $\mathrm{CO}_{2}$ to approximately $12 \mathrm{MPa}$ (which is slightly higher than the corresponding $P_{\mathrm{T}}$ of the monomer + $\mathrm{CO}_{2}$ system) so as to dissolve the added monomer. Then BPO (or AIBN) was added into the view cell via a set of high-pressure sample-in tube by the aid of the pressurized $\mathrm{CO}_{2}$ to initiate the polymerization. After the pressure was rapidly increased to $25 \mathrm{MPa}$ (within $3 \mathrm{~min}$ ), FT-NIR spectra were started to be in situ collected periodically during the polymerization processes, via which the monomer conversion was determined using the identical method recently reported [22]. When the system continuously polymerized for 8 hours or became cloudy [22,30,31] (where the baseline absorbance exceeded 3.0 [21]), the view cell was cooled and depressurized. After $\mathrm{CO}_{2}$ in the view cell was slowly released, the raw product was collected and characterized.

\subsection{Characterization}

Hydrogen nuclear magnetic resonance $\left({ }^{1} \mathrm{H}\right.$ NMR $)$ and carbon-13 nuclear magnetic resonance $\left({ }^{13} \mathrm{C}\right.$ NMR) spectra were detected via an Avance 400 superconducting Fourier digital NMR instrument ( $400 \mathrm{MHz}$ for proton, Bruker, Karlsruhe, Germany) in deuterated chloroform $\left(\mathrm{CDCl}_{3}\right)$ at $25^{\circ} \mathrm{C}$, where tetramethylsilane (TMS) and the residual chloroform in $\mathrm{CDCl}_{3}$ were used as references of chemical shift. The Fourier transform infrared (FT-IR) spectra of the products were measured using a Tensor 27 FT-IR spectrometer (Bruker, Karlsruhe, Germany) in potassium bromide $(\mathrm{KBr})$ disks in the wavenumber range of 4000 to $400 \mathrm{~cm}^{-1}$. The number-average molecular weight $\left(M_{n}\right)$ of the obtained non fluorinated polymers was analyzed using a Waters-Breeze gel permeation chromatography (GPC, Waters, Milford, CT, USA) where tetrahydrofuran (THF) was used as the eluent at a flow rate of $1.0 \mathrm{~mL} \cdot \mathrm{min}^{-1}$ and monodisperse polystyrene standards were applied to calibrate the relative molecular weight. The molecular weight of the poly 2,2,2-trifluoromethyl methacrylate (PMTFMA) was analyzed using a Microflex matrix-assisted laser desorption ionization time-of-flight mass spectrometry (MALDI-TOF mass, Bruker-Dalton, Bremen, Germany) followed a similar process to that in our recent work [22] except that dithranol was used as the matrix.

\section{Computational Methods}

The theoretical calculations have been performed using the Gaussian 2009 software package [32]. The geometries of monomer- $\left(\mathrm{CO}_{2}\right)_{\mathrm{n}}$ complexes as well as the monomer clusters are optimized using DFT-M062X/6-311G (2d, p) method which has been used in the similar system [33]. The absorption enthalpy $\left(\Delta \mathrm{H}_{\mathrm{abs}}\right)$ between the monomer and $\mathrm{CO}_{2}$ or two monomer molecules was calculated and used to evaluate the solubility of the monomers in $\mathrm{scCO}_{2}$. In such calculation the solvent treatment is not considered similarly to that reported in monomer $+\mathrm{scCO}_{2}$ system [23]. Moreover, the atomic charge of every monomer and the corresponding monomer radical and the binding energy during the addition of the monomer with the initial free radical are also calculated in the present work.

\section{Results and Discussion}

\subsection{Characterization of the Monomers and Obtained Polymers in $\mathrm{scCO}_{2}$}

The FT-IR (A), ${ }^{1} \mathrm{H}$ NMR (B)and ${ }^{13} \mathrm{C}$ NMR (C) spectra of MTFMA and the corresponding polymers (PMTFMA) are shown in Figures 1 and 2, in which the attribution of every spectrum is also presented. The MALDI-TOF mass spectrum of PMTFMA is shown in Figure 3. While since the spectra of PMMA and PMAA have been reported elsewhere, such results are not listed here. 


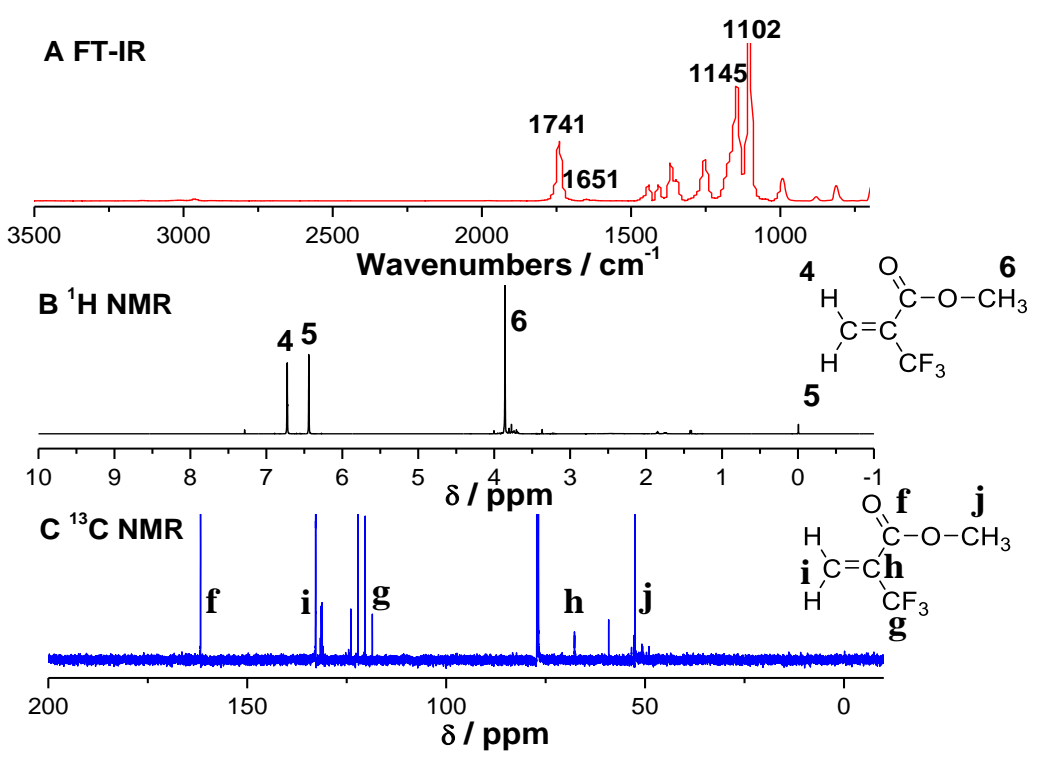

Figure 1. FT-IR (A), ${ }^{1} \mathrm{H}$ NMR (B) and ${ }^{13} \mathrm{C}$ NMR (C) spectra of MTFMA. FT-IR was measured in $\mathrm{KBr}$. disk. ${ }^{1} \mathrm{H}$ NMR spectra were recorded in $\mathrm{CDCl}_{3}$ at $25.0{ }^{\circ} \mathrm{C}$, TMS and the residual chloroform in $\mathrm{CDCl}_{3}$ were used as references of chemical shift.

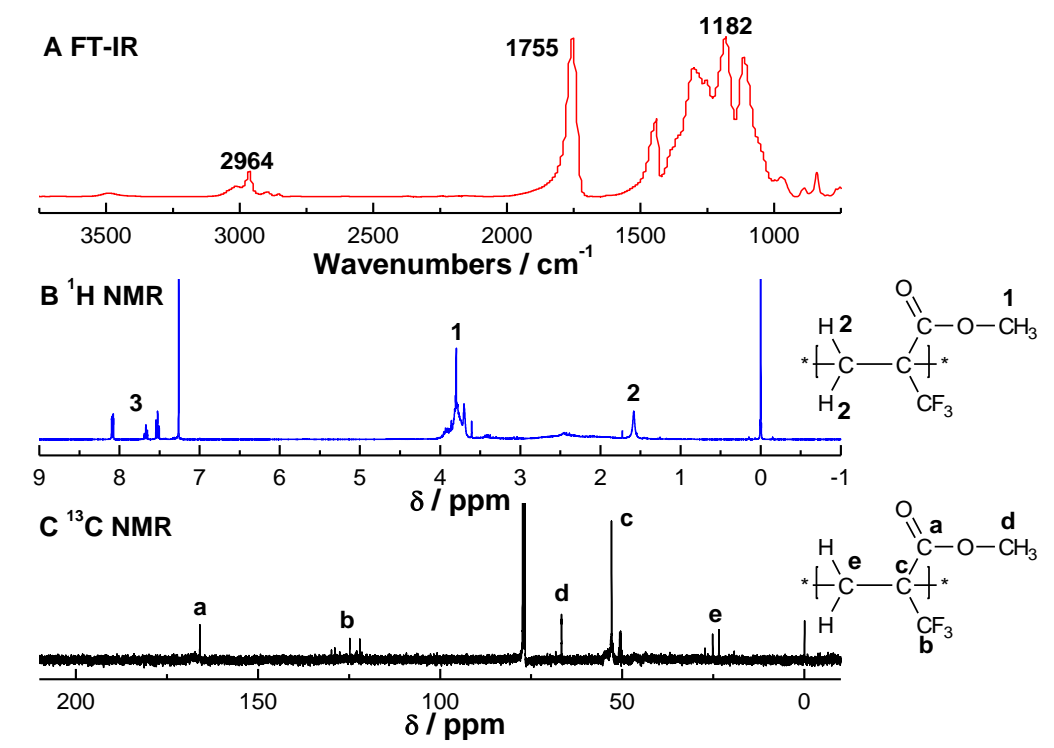

Figure 2. FT-IR (A), ${ }^{1} \mathrm{H}$ NMR (B) and ${ }^{13} \mathrm{C}$ NMR (C) spectra of PMTFMA synthesized in $\mathrm{scCO}_{2}$ at 60.0 ${ }^{\circ} \mathrm{C}$ under 25.0 MPa. The molar ration of MTFMA to BPO was 100:1.
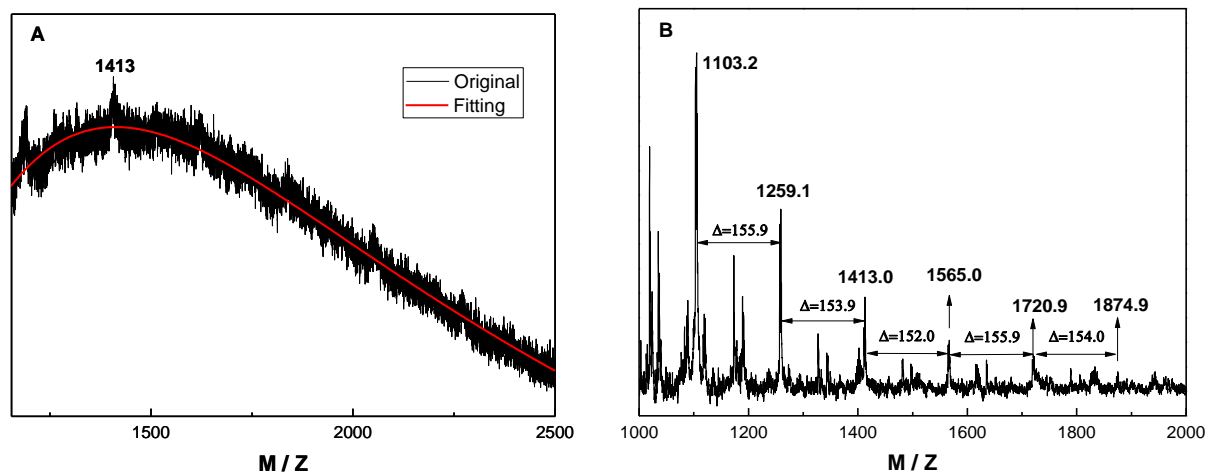

Figure 3. MALDI-TOF MS of PMTFMA synthesized in $\mathrm{scCO}_{2}$ at $60.0^{\circ} \mathrm{C}$ under $25.0 \mathrm{MPa}$. (A) Full MS spectrum, (B) expansion. The matrix was dithranol. 
As shown in the FTIR spectrum of PMTFMA in Figure 2A, the peaks at 1114 and $1182 \mathrm{~cm}^{-1}$ are attributed to the stretching vibration of C-F bonds $(v(C-F))$. Moreover, as compared with FT-IR spectrum of MTFMA (shown in Figure 1A), it is seen that the peak of $v(C=C)$ around $1630-1650 \mathrm{~cm}^{-1}$ disappeared. Additionally, $v(\mathrm{C}=\mathrm{O})$ is found to blue-shift from $1741 \mathrm{~cm}^{-1}$ (Figure $1 \mathrm{~A}$ ) to $1755 \mathrm{~cm}^{-1}$ due to the destruction of the $\pi-\pi$ conjugation effect in MTFMA. As shown in the ${ }^{1} \mathrm{H}$ NMR spectra of PMTFMA (Figure 2B) and MTFMA (Figure 1B), the olefinic $=\mathrm{CH}_{2}$ peaks in MTFMA (located at 6.44 and $6.23 \mathrm{ppm}$ ) completely disappeared. Furthermore, the chemical shift of $-\mathrm{OCH}_{3}$ slightly declined from $3.86 \mathrm{ppm}$ to $3.79 \mathrm{ppm}$ because of the previous $\mathrm{p}-\pi$ conjugation effect in MTFMA weakened. While the signal of the carbon atom in $-\mathrm{CF}_{3}$ (centered near $125 \mathrm{ppm}$ ) splits into multiple peaks mainly due to the spin coupling of the directly connected three $\mathrm{F}$ atoms, as shown in the ${ }^{13} \mathrm{C}$ NMR spectra of PMTFMA in Figure 2C. More importantly, as shown in the MALDI-TOF mass spectrum of PMTFMA in Figure $3 \mathrm{~A}$, the molecular weight is measured as $1413 \mathrm{~g} \cdot \mathrm{mol}^{-1}$. Additionally, it is seen that the intervals of marked peaks are all close to the molecular weight of MTFMA (154.1, shown in the expansion in Figure $3 \mathrm{~B})$. Since the spectral results mentioned above can be well attributed and confirmed with each other, it is indicated that MTFMA has been successfully polymerized in $\mathrm{scCO}_{2}$.

\subsection{Solvation Bahaviors of the Monomers in Gaseous and Supercritical $\mathrm{CO}_{2}$}

We believe that it is the intermolecular interactions in monomer/polymer $+\mathrm{CO}_{2}$ system that dominate the solvation process as well as the phase behaviors of monomer/polymer in $\mathrm{scCO}_{2}$ and may also play an important role to the polymerizability of the monomer in $\mathrm{scCO}_{2}$. Previously, we presented the concept of transition pressure $\left(P_{\mathrm{T}}\right)$ to demonstrate the unexpected vibrational absorption evolution of the functional groups during the solvation process of liquid monomers and polymers in gaseous and supercritical carbon dioxide [21,29]. $P_{\mathrm{T}}$ is defined as the lowest pressure at which the liquid solute could be completely dissolved or miscible with $\mathrm{scCO}_{2}$ under isothermal conditions. A lower $P_{\mathrm{T}}$ that the solute $+\mathrm{CO}_{2}$ presents, a better solubility that the solute has in $\mathrm{scCO}_{2}$. In the present work, the absorption band centers of $\mathrm{C}=\mathrm{O}$ and $\mathrm{C}-\mathrm{F}$ are extracted from the initial in situ FTIR spectra monitored via the high-pressure ATR-FTIR system and plotted versus the $\mathrm{CO}_{2}$ pressure. In this way, the absorption evolution of these functional groups in the MTFMA (MMA, MAA, TFMAA) $+\mathrm{CO}_{2}$ binary system of the probe functional groups $(v(\mathrm{C}-\mathrm{F})$ and $v(\mathrm{C}=\mathrm{O}))$ was sketched and from which the corresponding $P_{\mathrm{T}}$ of every binary system was measured, as shown in Figures 4-6.

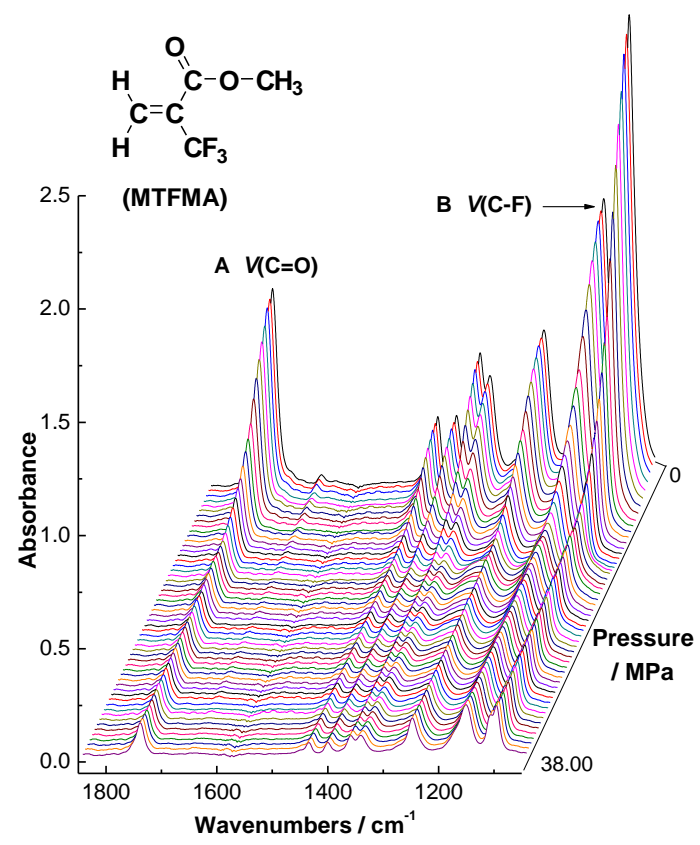

Figure 4. In situ FTIR spectra series of the MTFMA $+\mathrm{CO}_{2}$ binary system at $60.0^{\circ} \mathrm{C}$. 

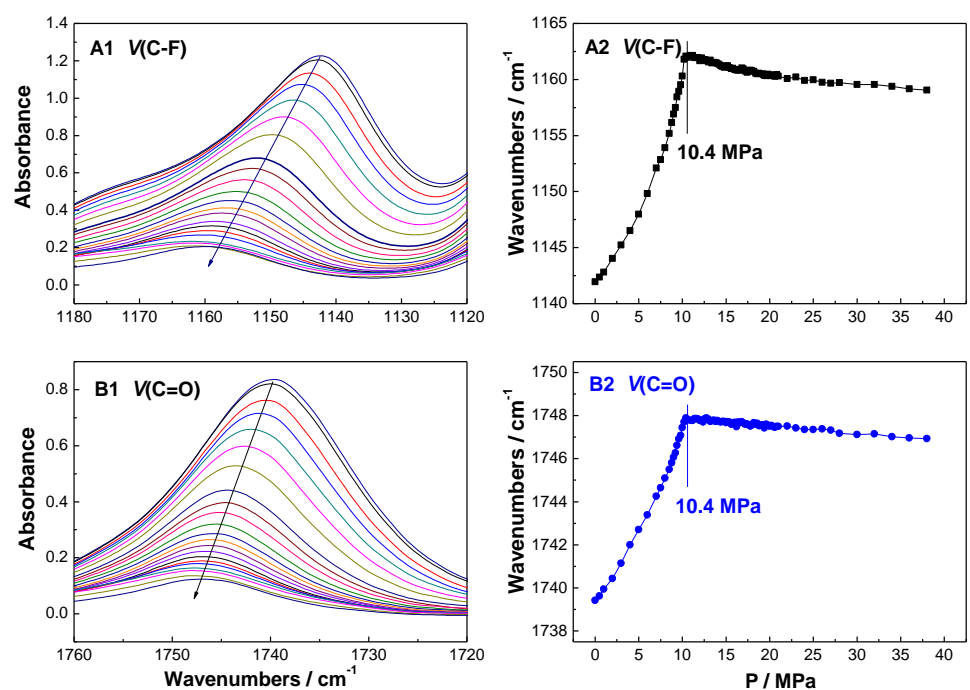

Figure 5. Vibrational absorption evolution of $(\mathbf{A 1}, \mathbf{A} 2) v(\mathrm{C}-\mathrm{F})$ and $(\mathbf{B} 1, \mathbf{B} 2) v(\mathbf{C}=\mathrm{O})$ in the MTFMA + $\mathrm{CO}_{2}$ binary system at $60.0^{\circ} \mathrm{C}$.

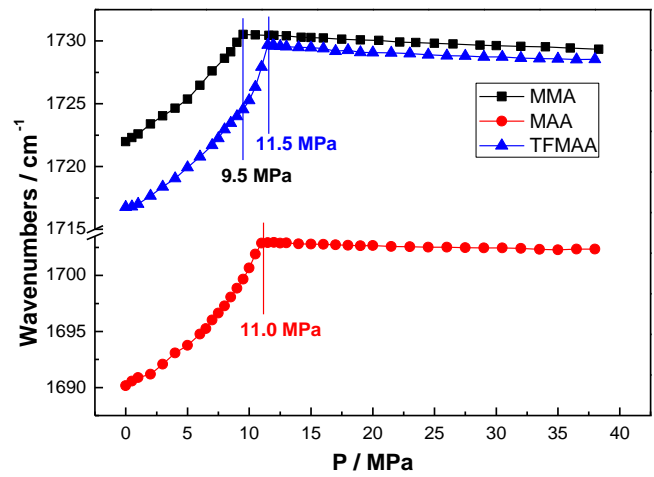

Figure 6. Vibrational absorption evolution of the functional groups in the MMA (MAA, TFMAA) + $\mathrm{CO}_{2}$ binary system at $60.0^{\circ} \mathrm{C}$.

As shown in Figures 4-6, it is found that the $P_{\mathrm{T}}$ of the MTFMA $+\mathrm{CO}_{2}$ system is measured as 10.4 $\mathrm{MPa}$ at $60.0^{\circ} \mathrm{C}$, either $v(\mathrm{C}-\mathrm{F})$ or $v(\mathrm{C}-\mathrm{O})$ was used as the probe. While at the identical temperature, the $P_{\mathrm{T}}$ of $\mathrm{MMA}+\mathrm{CO}_{2}, \mathrm{MAA}+\mathrm{CO}_{2}$ and TFMAA $+\mathrm{CO}_{2}$ system was obtained as $9.5 \mathrm{MPa}, 11.0 \mathrm{MPa}$ and $11.5 \mathrm{MPa}$, respectively. Such differences in the $P_{\mathrm{T}}$ values are attributed to the differences in the monomer structures and the resulted interactions in the corresponding monomer $+\mathrm{CO}_{2}$ system and are demonstrated as follows.

First, the carboxyl group and the resulted strong hydrogen bonding among the monomers are believed to negatively impact on the miscibility of the monomer with $\mathrm{CO}_{2}$ and thus contribute to a higher $P_{\mathrm{T}}$ of the binary system. While after the carboxyl group is esterified, the $P_{\mathrm{T}}$ is found to effectively decrease since the negative impact of hydrogen bonding is eliminated. For example, from TFMAA to MTFMA, the $P_{\mathrm{T}}$ of the corresponding binary system is found to decrease from $11.5 \mathrm{MPa}$ to 10.4 MPa, from MAA to MMA, the $P_{\mathrm{T}}$ of the system is found to decrease from 11.0 MPa to 9.5 MPa.

Second, the dispersion interaction among the monomers along with the attraction between $-\mathrm{CF}_{3}$ of the monomer and $\mathrm{CO}_{2}$ plays a contrary role to the miscibility of the monomer with $\mathrm{scCO}_{2}$. It is inferred that the dispersion interaction may play a predominant role in solvation behaviors of most monomers/polymers in $\mathrm{scCO}_{2}$ [21]. In view that the dispersion interaction among the monomers increases notably with the increase of the molecular weight $\left(M_{\mathrm{n}}\right)$, the corresponding $P_{\mathrm{T}}$ should also distinctly increase in the present work. While from MMA to MTFMA, the $M_{\mathrm{n}}$ increases by 54 , the $P_{\mathrm{T}}$ is found to increase only by $0.9 \mathrm{MPa}$. Similarly, the identical increase of $M_{\mathrm{n}}$ from MAA to TFMAA merely results in an increment of $0.5 \mathrm{MPa}$ in the $P_{\mathrm{T}}$ of the binary system. We believe that it is the attraction 
between $\mathrm{CO}_{2}$ and $-\mathrm{CF}_{3}$ in the fluorinated monomers, as well as the unique fluorine repulsion among the fluorinated molecules, that effectively weakens/counteracts the negative effects of the dispersion interaction among the monomers on the $P_{\mathrm{T}}$ of the binary system and thus contribute potently to the enhanced solubility of fluorinated monomers in $\mathrm{scCO}_{2}$.

So as to further discern the intermolecular interactions during the solvation process of the methacrylate monomers in $\mathrm{scCO}_{2}$, the theoretical calculations of DFT method is intentionally employed as the complement to the high pressure in situ FTIR technique.

\subsection{Calculation of the Intermolecular Interactions in Methacrylate $+\mathrm{CO}_{2}$ System}

We believe that the evolution of $\sigma(\mathrm{A}-\mathrm{B})$ (the average resultant force/interaction of the intermolecular interactions between the $\mathrm{CO}_{2}$ and the monomer) and $\sigma(\mathrm{B}-\mathrm{B})$ (the average resultant force/interaction of the self-interactions between the monomers) dominate the solvation behaviors of monomer in $\mathrm{scCO}_{2}$ [21,29]. So far, several function groups, such as $\mathrm{C}=\mathrm{O}$ [34], C-O [35], C-F [15], are reported to definitely contribute to $\sigma(\mathrm{A}-\mathrm{B})$ due to the special attraction between the specific group(s) and $\mathrm{CO}_{2}$. It is also reported that the interaction between the carbonyl group and $\mathrm{CO}_{2}$ may contribute more than that between $\mathrm{C}-\mathrm{F}$ and $\mathrm{CO}_{2}$ to the attraction of $\mathrm{FOA}$ with $\mathrm{CO}_{2}$ in $\mathrm{FOA}+\mathrm{scCO}_{2}$ system [22]. In the present work, $\mathrm{M} \ldots \mathrm{CO}_{2}$ is used to represent the cluster of monomer(s) with $\mathrm{CO}_{2}$ under lower $\mathrm{CO}_{2}$ pressure and $\mathrm{M} \ldots 3 \mathrm{CO}_{2}$ represents the cluster under higher $\mathrm{CO}_{2}$ pressure. While $\mathrm{M} \ldots \mathrm{M}$ is applied to describe the cluster of pure monomers. Moreover, the absorption enthalpy $\left(\Delta H_{\mathrm{abs}}\right)$ (which is defined as the enthalpy change during the formation of the $M \ldots \mathrm{nCO}_{2}$ cluster $(n=1,3)$ or the M...M cluster) is deliberately introduced to evaluate the magnitude/intensity of $\sigma(\mathrm{A}-\mathrm{B})$ or $\sigma(\mathrm{B}-\mathrm{B})$, so as to demonstrate the evolution of the resultant force/interaction with the increase of $\mathrm{CO}_{2}$ pressure and to certify/corroborate the intermolecular-interaction dynamically-induced solvation mechanism in $\mathrm{scCO}_{2}$ system. The optimized geometries of the lowest $\Delta H_{\mathrm{abs}}$ of $\mathrm{M} \ldots \mathrm{nCO}_{2}(\mathrm{n}=1,3)$ and $\mathrm{M} \ldots \mathrm{M}$, as well as the corresponding calculated $\Delta H_{\mathrm{abs}}$ of $\mathrm{M} \ldots \mathrm{nCO}_{2}(\mathrm{n}=1,3)$ and $\mathrm{M} \ldots \mathrm{M}$ are shown in Figures 7-9 and Table 1.

Table 1. $\Delta H_{\mathrm{abs}}(\mathrm{kJ} / \mathrm{mol})$ of the optimized geometries of $\mathrm{M} \ldots \mathrm{nCO}_{2}$ and $\mathrm{M} \ldots \mathrm{M}$.

\begin{tabular}{|c|c|c|c|c|c|c|}
\hline Entry & $\mathbf{M}$ & $\begin{array}{c}M_{n} \\
\text { (g.mol-1) } \\
\end{array}$ & $P_{\mathrm{T}}(\mathrm{MPa})$ & $\begin{array}{c}\Delta H_{\text {abs }}\left(\mathrm{M} \ldots \mathrm{CO}_{2}\right) \\
\mathrm{M}+\mathrm{CO}_{2} \rightarrow \mathrm{M} \ldots \mathrm{CO}_{2}\end{array}$ & $\begin{array}{c}\Delta H_{\text {abs }}\left(\mathrm{M} \ldots 3 \mathrm{CO}_{2}\right) \\
\mathrm{M}+3 \mathrm{CO}_{2} \rightarrow \mathrm{M} \ldots 3 \mathrm{CO}_{2}\end{array}$ & $\begin{array}{c}\Delta H_{\mathrm{abs}}(\mathrm{M} \ldots \mathrm{M}) \\
2 \mathrm{M} \rightarrow \mathrm{M} \ldots \mathrm{M}\end{array}$ \\
\hline 1 & MMA & 100.1 & 9.5 & -3.4 & -9.2 & -7.8 \\
\hline 2 & MAA & 86.1 & 11.0 & -4.4 & -10.4 & -70.1 \\
\hline 3 & MTFMA & 154.0 & 10.4 & -3.7 & -8.2 & -13.8 \\
\hline 4 & TFMAA & 140.1 & 11.5 & -4.6 & -7.3 & -103.6 \\
\hline
\end{tabular}

It can be seen that the monomer molecule may be better solvated by $\mathrm{CO}_{2}$ when the pressure increases since more stable cluster of $\mathrm{M} \ldots \mathrm{nCO}_{2}$ may form (shown in Figures 7 and 8). Moreover, as shown in Table 1 (Entry 1), the calculated $\Delta H_{\text {abs }}(\mathrm{M} \ldots \mathrm{M})$ is found to be more than twice of $\Delta H_{\mathrm{abs}}(\mathrm{M}$ $\ldots \mathrm{CO}_{2}$ ), indicating that the average resultant interaction between MMA is stronger than that between $\mathrm{CO}_{2}$ and MMA under lower $\mathrm{CO}_{2}$ pressure, namely, $\sigma(\mathrm{B}-\mathrm{B})>\sigma(\mathrm{A}-\mathrm{B})$. More importantly, it is clearly seen that the obtained $\Delta H_{\mathrm{abs}}\left(\mathrm{M} \ldots 3 \mathrm{CO}_{2}\right)(-9.2 \mathrm{~kJ} / \mathrm{mol})$ is distinctly higher than $\Delta H_{\mathrm{abs}}\left(\mathrm{M} \ldots \mathrm{CO}_{2}\right)$ $(-3.4 \mathrm{~kJ} / \mathrm{mol})$, certifying that $\sigma(\mathrm{A}-\mathrm{B})$ increases with the increase of $\mathrm{CO}_{2}$ pressure. Contrarily, the initially strong $\sigma(\mathrm{B}-\mathrm{B})$ may be gradually weakened/undermined because of the slight electron redistribution along with the expansion of MMA by $\mathrm{CO}_{2}$ during pressuring [20]. With the increase of $\mathrm{CO}_{2}$ pressure, $\sigma(\mathrm{A}-\mathrm{B})$ may increase further, versus that $\sigma(\mathrm{B}-\mathrm{B})$ is increasingly weakened. There must be a pressure value where $\sigma(\mathrm{A}-\mathrm{B})$ may equal to $\sigma(\mathrm{B}-\mathrm{B})$, the macroscopic force on the MMA molecule may equilibrate and MMA may completely disperse and fully miscible with $\mathrm{CO}_{2}$ under isothermal condition. Such pressure is exactly the $P_{\mathrm{T}}$ of $\mathrm{MMA}+\mathrm{CO}_{2}$ system, which has been accurately determined via our high-pressure FTIR monitoring system $(9.5 \mathrm{MPa})$. It is inferred that, as the $\mathrm{CO}_{2}$ pressure further increased, $\sigma(\mathrm{A}-\mathrm{B})$ may probably become greater than $\sigma(\mathrm{B}-\mathrm{B})$, which has been partly proved and for the obtained $\Delta H_{\text {abs }}\left(\mathrm{M} \ldots 3 \mathrm{CO}_{2}\right)$ the value is found to be higher than that of the initial $\Delta H_{\text {abs }}(\mathrm{M} \ldots \mathrm{M})$ $(-7.8 \mathrm{~kJ} / \mathrm{mol})$. 


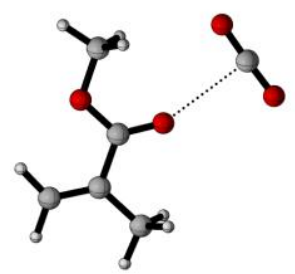

MMA.... $\mathrm{CO}_{2}$

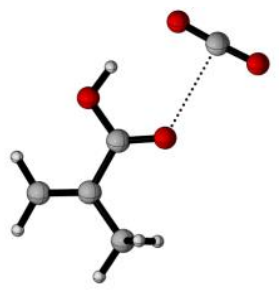

MAA..... $\mathrm{CO}_{2}$

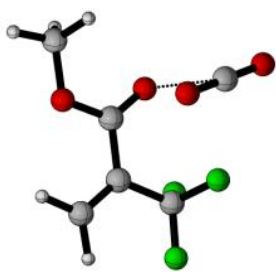

MTFMA..... $\mathrm{CO}_{2}$

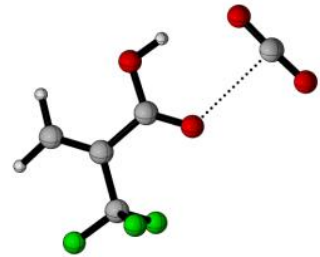

TFMAA..... $\mathrm{CO}_{2}$

Figure 7. Optimized geometries of the lowest energies for $\mathrm{M} \ldots \mathrm{CO}_{2}$ clusters.

Similarly, the solvation behaviors of MTFMA in gaseous and supercritical $\mathrm{CO}_{2}$ can also be well understood via the calculation as well as the IDISE hypothesize. While the calculated $\Delta H_{\mathrm{abs}}(\mathrm{M} \ldots$ M) in MTFMA is found to be obviously higher than that in MMA (partly due to the increase in $M_{n}$ ), resulting in a higher $P_{\mathrm{T}}$ of MTFMA $+\mathrm{CO}_{2}$ system.

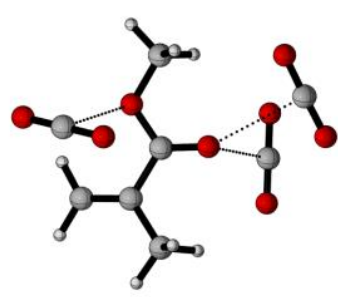

MMA...3 $\mathrm{CO}_{2}$

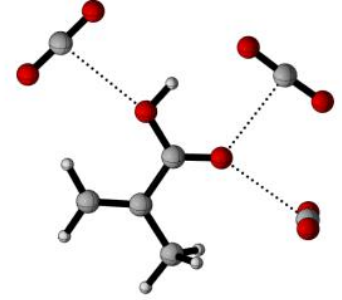

MAA...3 $3 \mathrm{CO}_{2}$

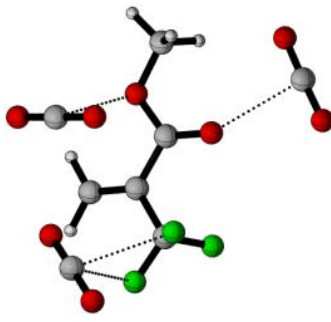

MTFMA...3 $\mathrm{CO}_{2}$

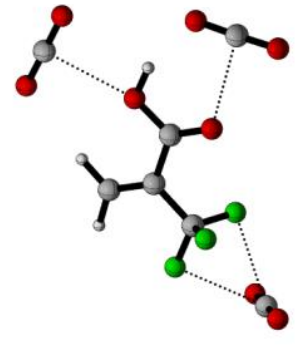

TFMAA...3 $3 \mathrm{CO}_{2}$

Figure 8. Optimized geometries of the lowest energies for $\mathrm{M} \ldots 3 \mathrm{CO}_{2}$ clusters.

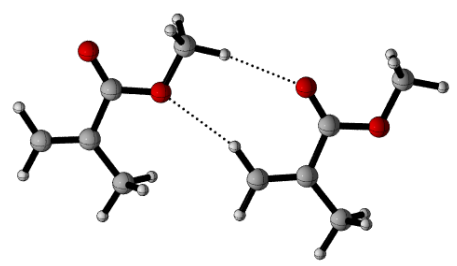

MMA...MMA

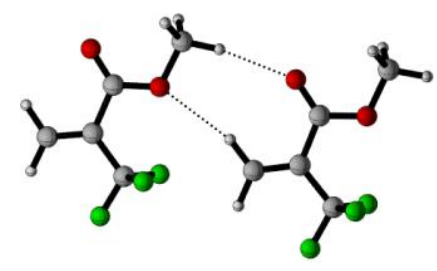

MTFMA...MTFMA

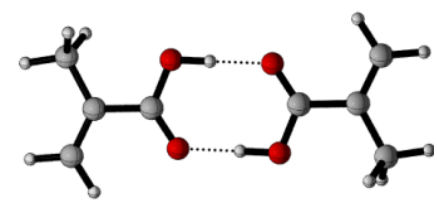

MAA...MAA

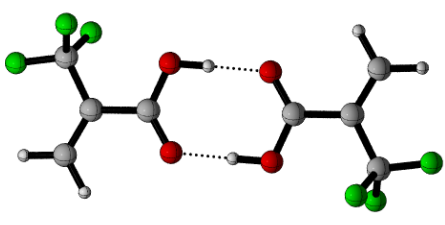

TFMAA...TFMAA

Figure 9. Optimized geometries of the lowest energies for M ... M clusters.

Unexpectedly, the obtained $\Delta H_{\mathrm{abs}}(\mathrm{M} \ldots \mathrm{M})$ in MAA $(-70.1 \mathrm{~kJ} / \mathrm{mol})$ or TFMAA $(-103.6 \mathrm{~kJ} / \mathrm{mol})$ is found to be dramatically higher than that in MMA or MTFMA, suggesting that the $\sigma(B-B)$ in these systems may be severely greater than that in MMA or MTFMA. Such strong self-interactions are believed to be mainly derived from the existence of $-\mathrm{COOH}$ and the resulted effective hydrogen bonding in the system. Moreover, it is clearly that the initial value of $\Delta H_{\mathrm{abs}}(\mathrm{M} \ldots \mathrm{M})$ is considerably greater than that of $\triangle H_{\text {abs }}\left(\mathrm{M} \ldots 3 \mathrm{CO}_{2}\right)$ in $\mathrm{MAA}+\mathrm{CO}_{2}$ system, indicating that the self-interaction of $\sigma(\mathrm{B}-\mathrm{B})$ may be too strong to be surpassed by $\sigma(\mathrm{A}-\mathrm{B})$, even $\mathrm{CO}_{2}$ pressure is considerably high. In this case, MAA must exist in form of clusters instead of single molecule in $\mathrm{scCO}_{2}$, especially in the dimer form, as shown in Figure 9. Additionally, probably owing to the strong electron-withdrawing 
effect of $-\mathrm{CF}_{3}$ in TFMAA, the intermolecular hydrogen bonding among TFMAA is predicted to be further enhanced, leading to a greater $\sigma(\mathrm{B}-\mathrm{B})$ in TFMAA. Such prediction has been largely proved since the calculated $\triangle H_{\text {abs }}(\mathrm{M} \ldots \mathrm{M})$ in TFMAA is much greater than that of the other three methacrylate monomers, along with that the experimentally measured $P_{\mathrm{T}}$ of TFMAA $+\mathrm{CO}_{2}$ system is the highest among that of the four methacrylate $+\mathrm{CO}_{2}$ systems in the present work. It is inferred that the TFMAA ... TFMAA clusters may restrain the diffusion of TFMAA in $\mathrm{scCO}_{2}$ and decrease the polymerizability of TFMAA in $\mathrm{scCO}_{2}$ to some extent.

Based on the calculation mentioned above, it is clear that the $\Delta H_{\mathrm{abs}}$ may be a rational and promising function to evaluate the evolution of $\sigma(\mathrm{A}-\mathrm{B})$ and $\sigma(\mathrm{B}-\mathrm{B})$ during the solvation process of the monomers in $\mathrm{CO}_{2}$. In view that the predicted order of the solubility of the four monomers inscCO $\mathrm{CO}_{2}$ (MMA > MTFMA > MAA > TFMAA) is ideally consistent with that of the experimental $P_{\mathrm{T}}$ (MMA $<$ MTFMA $<$ MAA $<$ TFMAA), it is believed that the previously proposed mechanism of intermolecular-interaction dynamically-induced solvation effect (IDISE) of monomer in $\mathrm{scCO}_{2}$ system is well certified/corroborated.

\subsection{Free Radical Polymerization of the Monomers in $\mathrm{scCO}_{2}$}

The free radical polymerization of the four monomers in $\mathrm{scCO}_{2}$ was investigated so as to understand the impacts of the monomer structure, especially $-\mathrm{CF}_{3}$ in the alkyl 2-trifluoromethacrylate(s), on the polymerizability of the monomer. The results are listed in Table 2.

Table 2. Results for the free radical polymerization of the monomers in $\mathrm{scCO}_{2}{ }^{\mathrm{a}}$.

\begin{tabular}{|c|c|c|c|c|}
\hline Entry & Monomer & Reaction Time/h & Conversion $/ \%$ b & Molecular Weight $/ \mathrm{g} \cdot \mathrm{mol}^{-1}$ \\
\hline 1 & MMA & 4 & 30.7 & $57817^{c}$ \\
\hline 2 & MAA & 8 & 70.5 & $23800^{c}$ \\
\hline 3 & MTFMA & 8 & 3.1 & $1413^{\mathrm{d}}$ \\
\hline 4 & MTFMA & 40 & 10.8 & $1634^{\mathrm{d}}$ \\
\hline 5 & TFMAA & \multicolumn{3}{|c|}{ cannot be polymerized ${ }^{\mathrm{e}}$} \\
\hline
\end{tabular}

${ }^{a}$ Free radical polymerization was carried out at $60.0^{\circ} \mathrm{C}$ and $25.0 \mathrm{MPa}$. The molar ratio of the monomer to BPO was $100 / 1$ ( $\mathrm{mol} / \mathrm{mol}) .{ }^{\mathrm{b}}$ Conversion was calculated via HP FT-NIR. ${ }^{c} M_{n}$ of the synthesized nonfluorinated polymers were analyzed using GPC. ${ }^{\mathrm{d}} M_{\mathrm{n}}$ of the PMTFMA was analyzed using MALDI-TOF mass (as shown in Figure 2). ${ }^{\mathrm{e}}$ No polymeric product is obtained whatever the free radical polymerization of TFMAA were performed in $\mathrm{scCO}_{2}$, trifluorotoluene or toluene and initiated by AIBN or BPO.

As shown in Table 2, it is clear that MMA and MAA can be easily polymerized under the experimental conditions mentioned above. For example, after polymerized for 8 hours, the conversion of MAA reaches to $70.5 \%$ and the $M_{n}$ comes up to 23,800 . While for MTFMA, it is found that at the identical polymerization time to that in MAA, the conversion of MTFMA is $3.1 \%$. Even if the polymerization lasts for $40 \mathrm{~h}$, the conversion is merely $10.8 \%$. Simultaneously, the molecular weight of the polymeric product is found to be severely low as 1634 . Namely, the polymerization degree is around 10. It is shown that the free radical polymerizability of MTFMA is considerably poor, though such monomer has been polymerized via the initiation of BPO in the present work. What's more, it is found that TFMAA cannot be polymerized by the initiation of free radical initiator in either $\mathrm{scCO}_{2}$ or organic solvent. Clearly, $-\mathrm{CF}_{3}$ may significantly decrease the free radical polymerization activity of the corresponding methacrylate(s) in $\mathrm{scCO}_{2}$.

We believe that the existence of $-\mathrm{CF}_{3}$ and the resulted strong electron-withdrawing effect may distinctly change the electron distribution in $\mathrm{C}=\mathrm{C}$. May this be the reason for the reduction of polymerizability of the MTFMA and TFMAA? Theoretical calculation of DFT-M062X/6-311G (2d, p) method was employed to understand the homopolymerization activity of the monomers in $\mathrm{scCO}_{2}$, especially the contribution of $-\mathrm{CF}_{3}$ to the free radical polymerizability of MTFMA in $\mathrm{scCO}_{2}$. The atomic charge of every monomer $(\mathrm{M})$ and the corresponding monomer radical (IM., produced by the 
addition of the monomer with the initial free radical I) and binding energy $(\triangle E$, the energy change in the formation of IM, I + M $\rightarrow \mathrm{IM}$ ) of every monomer with I· are calculated and listed in Table 3.

Table 3. Geometric parameters and the binding energy of every monomer with $\mathrm{I}$.<smiles>[R]OC(=O)C([R2])=C</smiles>

M<smiles>[R]OC(=O)C([R2])COC(=O)c1ccccc1</smiles>

IM-
$\mathrm{I}^{*}=$<smiles>[O]C(=O)c1ccccc1</smiles>

$\mathrm{R}_{1}=\mathrm{H}, \mathrm{CH}_{3}$

$\mathrm{R}_{2}=\mathrm{H}, \mathrm{CF}_{3}$

\begin{tabular}{|c|c|c|c|c|c|}
\hline Entry & Parameter & MMA & MAA & MTFMA & TFMAA \\
\hline & \multicolumn{5}{|c|}{ Atomic charge of $\mathrm{R} / \mathrm{e}$} \\
\hline 1 & $1 C$ & -0.300 & -0.293 & -0.235 & -0.223 \\
\hline 2 & $2 \mathrm{C}$ & -0.137 & -0.145 & -0.245 & -0.272 \\
\hline 3 & $3 C$ & 0.825 & 0.819 & 0.828 & 0.820 \\
\hline 4 & $4 \mathrm{O}$ & -0.619 & -0.619 & -0.608 & -0.575 \\
\hline 5 & $5 \mathrm{O}$ & -0.573 & -0.715 & -0.556 & -0.685 \\
\hline \multirow[t]{2}{*}{6} & 6C(in IM·) & 0.062 & 0.072 & 0.027 & -0.009 \\
\hline & \multicolumn{5}{|c|}{ Binding energy $/ \mathrm{kJ} \cdot \mathrm{mol}^{-1}$} \\
\hline 7 & $\begin{array}{c}\Delta \mathrm{E}(\mathrm{I} \cdot+ \\
\mathrm{M} \rightarrow \mathrm{IM} \cdot)\end{array}$ & -95.513 & -100.960 & -77.239 & -79.138 \\
\hline
\end{tabular}

As shown in Table 3 (Entry 1), it is found that after $-\mathrm{CH}_{3}$ is replaced by $-\mathrm{CF}_{3}$, the absolute value of the atomic charge of $\mathrm{C} 1$ in $\mathrm{C}=\mathrm{C}$ distinctly decreases. For example, it declines from $0.300 \mathrm{e}$ (in MMA) to 0.235 e (in MTFMA) or from 0.293 e (in MAA) to 0.223 e (in TFMAA). It is believed that such a decrease in the atomic charge of $\mathrm{C} 1$ in MTFMA or TFMAA is predominantly derived from the strong electron-with drawing inductive effect of $-\mathrm{CF}_{3}$ to $\mathrm{C}=\mathrm{C}$ and the resulted electron redistribution in $\mathrm{C}=\mathrm{C}$ (namely, the electron between $\mathrm{C} 1$ and $\mathrm{C} 2$ may shift to $\mathrm{C} 2$ to some extent) and may be mainly responsible for the decline of the free radical polymerizability of MTFMA and TFMAA. Possible reasons are presented as follows.

First, generally, $\mathrm{C} 1$ in $\mathrm{C}=\mathrm{C}$ is much easier to be attacked by the initial free radicals since the steric hindrance of $\mathrm{C} 1$ is much smaller than that of $\mathrm{C} 2$ in methacrylate monomers along with that more favorable/stable intermediate of monomer radical IM may be produced if $\mathrm{C} 1$ of the monomer is bonded with the initial free radical. In this case, it is suggested that the decrease in the atomic charge of $\mathrm{C} 1$ may be severely unfavorable for the chain initiation. Such suggestion is believed to be verified by the calculation of the binding energy. For example, it is seen in Table (Entry 7) that the absolute value of the binding energy of MTFMA with I. $\left(77.239 \mathrm{~kJ} \cdot \mathrm{mol}^{-1}\right)$ is clearly found to be much lower than that of MMA with the identical I. $\left(95.513 \mathrm{~kJ} \cdot \mathrm{mol}^{-1}\right)$, indicating that the initiation activity of I. may decline significantly when MTFMA is used instead of MMA. Similar results can also be obtained when TFMAA is applied instead of MAA.

Second, the chain propagation activity may dramatically decline in step with the decrease of atomic charge of $\mathrm{C} 1$ in $\mathrm{C}=\mathrm{C}$. As shown in Table 3 (Entry 6), the absolute value of the atomic charge of $\mathrm{C} 6$ is found to be considerably small when MMA or MAA is in involved in the monomer radical of IM- and which is even smaller in the monomer radical of I- with MTFMA or TFMAA. Moreover, with regard to the chain propagation, the steric hindrance of C6 in IM is obviously bigger than that of $\mathrm{C} 2$ in the corresponding monomer, especially when MTFMA or TFMAA is polymerized. These two factors are both unfavorable for the chain growth during the free radical polymerization. In this case, the monomer should be active enough if the monomer/polymer chain is expected to continuously propagate, namely, the polymerization successfully occurs. It is inferred that the electron distribution in $\mathrm{C}=\mathrm{C}$, especially the atomic charge in $\mathrm{C} 1$ of the monomer, may play a key role to the free radical 
polymerizability of the methacrylate monomers. The bigger the absolute value of the atomic charge of $\mathrm{C} 1$ in $\mathrm{C}=\mathrm{C}$ is, the more easily the chain propagates.

Pulsed laser polymerization (PLP) is reported to be an effective technique to determine the propagation rate coefficients $(\mathrm{kp})$ of a series of monomers (MMA, MAA, styrene and vinylidene fluoride, etc.) in the free radical polymerization in both $\mathrm{scCO}_{2}$ and organic solvent systems [36-38]. While the report on such determination of the alkyl 2-trifluoromethacrylate(s) monomer (such as MTFMA or TFMAA) has not been seen/available so far. Moreover, ab initio calculations are also used to investigate the polymerization kinetics [39,40]. It is expected that these methods may be successfully applied in the next work so as to achieve further understanding on the polymerizability of alkyl 2-trifluoromethacrylate(s) as well as other fluorinated monomers in $\mathrm{scCO}_{2}$.

In brief, since the absolute value of the atomic charge of C1 in MTFMA or TFMAA is distinctly small as compared with that in MMA or MAA, the chain initiation as well as the chain propagation of MTFMA or TFMAA is predicted to be severely difficult to occur, which is well in accordance with what has been observed experimentally in the free radical polymerization in the present work.

\section{Conclusions}

The solvation behaviors and the free radical homopolymerization of four methacrylate monomers, including MMA, MAA, MTFMA and TFMAA in $\mathrm{ScCO}_{2}$ were systematically investigated via HP FTIR/NIR technology along with the theoretical calculation of DFT-M062X/6-311G (2d, p) method in the present work. The intermolecular interactions of every monomer $+\mathrm{CO}_{2}$ system during the solvation is demonstrated and discerned via the concepts of $P_{\mathrm{T}}, \sigma(\mathrm{A}-\mathrm{B}), \sigma(\mathrm{B}-\mathrm{B})$ and $\Delta H_{\mathrm{abs}}$, via which the solubility of the monomer in $\mathrm{scCO}_{2}$ is successfully evaluated and the previously proposed mechanism of intermolecular-interaction dynamically-induced solvation effect (IDISE) of monomer in $\mathrm{scCO}_{2}$ may be well verified/corroborated. More importantly, the homopolymerization activity of the four methacrylates in $\mathrm{scCO}_{2}$, especially the special contribution of $-\mathrm{CF}_{3}$ to the free radical polymerizability of MTFMA in $\mathrm{scCO}_{2}$ is revealed. The free radical polymerization of MMA and MAA in $\mathrm{scCO}_{2}$ is easy to occur, while that of MTFMA is much difficult though it does have been successfully polymerized via the initiation of BPO. TFMAA cannot be polymerized via the free radical initiators. It is believed that there are mainly two factors that are predominantly answer for the significant decline of the free radical polymerizability of MTFMA, TFMAA and other alkyl 2-trifluoromethacrylates in $\mathrm{scCO}_{2}$. First, the diffusion of the monomer in $\mathrm{scCO}_{2}$ may be restrained since the intermolecular hydrogen bonding is enhanced by $-\mathrm{CF}_{3}$. Second, the atomic charge of $\mathrm{C} 1$ in $\mathrm{C}=\mathrm{C}$ may be the distinctly decreased by the strong electron-withdrawing inductive effect of $-\mathrm{CF}_{3}$ to $\mathrm{C}=\mathrm{C}$. Whereas there are still many issues to be further solved, the present work may be the first example that successfully combine the HP FTIR/NIR technology with the DFT method to explore and disclose the intermolecular interaction mechanism as well as the free radical polymerizability of methacrylate in $\mathrm{scCO}_{2}$ and is expected to improve the research and application in many related fields.

Author Contributions: Experimental data curation: R.-Q.L. and M.-X.W.; validation, J.-G.C.; theoretical calculation, K.W., X.-Y.Z. and Z.-W.L.; formal analysis, Q.-Y.Z., S.S. and J.J.; writing-original draft preparation, R.-Q.L. and M.-X.W.; writing-review and editing, J.-G.C. and Z.-T.L.; supervision, J.-G.C. and Z.-T.L. All authors have read and agreed to the published version of the manuscript.

Funding: This research was funded by the National Natural Science Foundation of China $(21773148,21306111$, 21327011), Natural Science Foundation of Shaanxi Province (2018JM2003, 2018JM2016) and the Fundamental Research Funds for the Central Universities (GK1301030235, GK201803040).

Acknowledgments: The authors gratefully acknowledge the financial support of the National Natural Science Foundation of China (21306111, 21327011, 21773148), Natural Science Foundation of Shaanxi Province (2018JM2003, 2018JM2016) and the Fundamental Research Funds for the Central Universities (GK1301030235, GK201803040).

Conflicts of Interest: The authors declare no conflict of interest. 


\section{References}

1. Kuliasha, C.A.; Fedderwitz, R.L.; Calvo, P.R.; Sumerlin, B.S.; Brennan, A.B. Engineering the surface properties of poly (dimethylsiloxane) utilizing aqueous RAFT photo grafting of acrylate/methacrylate monomers. Macromolecules 2018, 51, 306-317. [CrossRef]

2. Amicia, J.; Romanina, S.; Alidoosta, M.; Versacia, D.; Franciaa, C.; Smeacettob, F.; Bodoardoa, S. UV-cured methacrylate based polymer composite electrolyte for metallic lithium batteries. J. Electroanal. Chem. 2019, 837, 103-107. [CrossRef]

3. Urosev, I.; Dorrington, H.; Muzzin, N.; Alsop, R.; Bakaic, E.; Gilbert, T.; Rheinstadter, M.; Hoare, T. Injectable Poly (oligoethylene glycol methacrylate)-based hydrogels fabricated from highly branched precursor polymers: Controlling gel properties by precursor polymer morphology. ACS Appl. Polym. Mater. 2019, 1, 369-380. [CrossRef]

4. Couturaud, B.; Georgiou, P.G.; Varlas, S.; Jones, J.R.; Arno, M.C.; Foster, J.C.; O’Reilly, R.K. Poly(pentafluorophenyl methacrylate)-based nano-objects developed by photo-PISA as scaffolds for post-polymerization functionalization. Macromol. Rapid Commun. 2019, 40, 1800460. [CrossRef]

5. Discekici, E.H.; Anastasaki, A.; Kaminker, R.; Willenbacher, J.; Truong, N.P.; Fleischmann, C.; Oschmann, B.; Lunn, D.J.; de Alaniz, J.R.; Davis, T.P.; et al. Light-mediated atom transfer radical polymerization of semifluorinated (meth)acrylates: Facile access to functional materials. J. Am. Chem. Soc. 2017, 139, 5939-5945. [CrossRef]

6. Zhang, K.Q.; Li, X.H.; Zhao, Y.H.; Zhu, K.Y.; Li, Y.C.; Tao, C.; Yuan, X.Y. UV-curable POSS-fluorinated methacrylate diblock copolymers for icephobic coatings. Prog. Org. Coat. 2016, 93, 87-96. [CrossRef]

7. Ye, X.Y.; Zuo, B.; Deng, M.; Hei, Y.L.; Ni, H.G.; Lu, X.L.; Wang, X.P. Surface segregation of fluorinated moieties on poly(methyl methacrylate-ran-2-perfluorooctylethyl methacrylate) films during film formation: Entropic or enthalpic influences. J. Colloid Interface Sci. 2010, 349, 205-214. [CrossRef]

8. Yin, M.; Guo, S.; Liu, F.; He, J.W. Synthesis of fluorinated dimethacrylate monomer and its application in preparing Bis-GMA free dental resin. J. Mech. Behav. Biomed. Mater. 2015, 51, 337-344. [CrossRef]

9. Liu, J.Y.; Haynes, D.; Balliet, C.; Zhang, R.; Kowalewski, T.; McCullough, R.D. Self encapsulated poly(3-hexylthiophene)-poly(fluorinated alkyl methacrylate) rod-coil block copolymers with high field effect mobilities on bare $\mathrm{SiO}_{2}$. Adv. Funct. Mater. 2012, 22, 1024-1032. [CrossRef]

10. Patil, Y.; Ameduri, B. Advances in the (co)polymerization of alkyl 2-trifluoromethacrylates and 2-(trifluoromethyl)acrylic acid. Prog. Polym. Sci. 2013, 38, 703-739. [CrossRef]

11. Ito, H.; Miller, D.C.; Willson, C.G. Polymerization of methyl $\alpha$-(trifluoromethyl)acrylate and $\alpha$-(trifluoromethyl)acrylonitrile and copolymerization of these monomers with methyl methacrylate. Macromolecules 1982, 15, 915-920. [CrossRef]

12. Dickey, J.B. Polymers of Alpha-Fluoromethyl Acrylic Acid Esters. US Patent 2,472,811, 14 June 1949.

13. Girard, E.; Tassaing, T.; Camy, S.; Condoret, J.S.; Marty, J.D.; Destarac, M. Enhancement of poly (vinyl ester) solubility in supercritical $\mathrm{CO}_{2}$ by partial fluorination: The key role of polymer-polymer interactions. J. Am. Chem. Soc. 2012, 134, 11920-11923. [CrossRef] [PubMed]

14. Girard, E.; Tassaing, T.; Ladavière, C.; Marty, J.D.; Destarac, M. Distinctive features of solubility of RAFT/MADIX-derived partially trifluoromethylatedpoly(Vinyl Acetate) in supercritical $\mathrm{CO}_{2}$. Macromolecules 2012, 45, 9674-9681. [CrossRef]

15. Girard, E.; Tassaing, T.; Marty, J.D.; Destarac, M. Structure-property relationships in $\mathrm{CO}_{2}$-philic (co)polymers: Phase behavior, self-assembly and stabilization of Water/CO $\mathrm{CO}_{2}$ emulsions. Chem. Rev. 2016, 116, 4125-4169. [CrossRef]

16. Boyère, C.; Jérôme, C.; Debuigne, A. Input of supercritical carbon dioxide to polymer synthesis: An overview. Eur. Polym. J. 2014, 61, 45-63. [CrossRef]

17. Desimone, J.M.; Guan, Z.; Elsbernd, C.S. Synthesis of fluoropolymers in supercritical carbon dioxide. Science 1992, 257, 945-947. [CrossRef]

18. Combes, J.R.; Guan, Z.; DeSimone, J.M. Homogeneous free-radical polymerizations in carbon dioxide. 3. Telomerization of 1, 1-difluoroethylene in supercritical carbon dioxide. Macromolecules 1994, 27, 865-867. [CrossRef]

19. Du, L.; Kelly, J.Y.; Roberts, G.W.; DeSimone, J.M. Fluoropolymer synthesis in supercritical carbon dioxide. J. Supercrit. Fluids 2009, 47, 447-457. [CrossRef]

20. Chen, J.-G.; Liu, X.; Liu, Z.-W.; Hu, D.-D.; Zhang, C.; Xue, D.; Xiao, J.-L.; Liu, Z.-T. Intermolecular-interactiondominated solvation behaviors of liquid monomers and polymers in gaseous and supercritical carbon dioxide. Macromolecules 2012, 45, 4907-4919. [CrossRef] 
21. He, Q.; Wang, K.; Chen, J.G.; He, Z.H.; Liu, Z.T.; Liu, Z.W.; Lu, J. Interaction between ammonium perfluorooctanoate and $\mathrm{CO}_{2}$ and its removal from fluoropolymer in supercritical carbon dioxide. Sep. Purif. Technol. 2020, 232, 115955. [CrossRef]

22. Chen, J.-G.; Feng, X.; Wang, M.-X.; Shen, S.K.; Li, Y.; Wang, W.; Liu, Z.-T.; Liu, Z.-W.; Jiang, J.-Q.; Jian, L. Controlled radical polymerization of fluorinated methacrylates in supercritical $\mathrm{CO}_{2}$ : Synthesis and application of a novel RAFT agent. J. Polym. Sci. Part A Polym. Chem. 2016, 54, 825-834. [CrossRef]

23. Liu, X.; Coutelier, O.; Harrisson, S.; Tassaing, T.; Marty, J.-D.; Destarac, M. Enhanced solubility of polyvinyl esters in $\mathrm{scCO}_{2}$ by means of vinyl trifluorobutyrate monomer. ACS Macro Lett. 2015, 4, 89-93. [CrossRef]

24. Ingrosso, F.; Ruiz-López, M.F. Modeling solvation in supercritical $\mathrm{CO}_{2}$. ChemPhysChem 2017, 18, $2560-2572$. [CrossRef] [PubMed]

25. Wang, J.; Wang, M.; Hao, J.; Fujita, S.I.; Arai, M.; Wu, Z.; Zhao, F. Theoretical study on interaction between $\mathrm{CO}_{2}$ and carbonyl compounds: Influence of $\mathrm{CO}_{2}$ on infrared spectroscopy and activity of C=O. J. Supercrit. Fluids 2010, 54, 9-15. [CrossRef]

26. Liu, Z.-T.; Chen, J.-G.; Liu, X.; Liu, Z.-W. High-Pressure In Situ Infrared Spectroscopy Device for On-Line Monitoring of Supercritical System. Chinese Patent CN 102435573 B, 25 December 2013.

27. Chen, J.-G.; Wang, K.; Liu, Z.-T.; Shen, S.-K.; Zhou, G.-G.; Liu, Z.-W.; Jiang, J.Q.; Song, L.P. High-Pressure Uv-Visible-Nir Spectrometer Device for Online Monitoring of Supercritical System. Chinese Patent CN 103712931 B, 17 August 2016.

28. Lazzaria, M.; Aglietto, M.; Castelvetro, V.; Chiantore, O. Photochemical stability of partially fluorinated acrylic protective coatings IV. Copolymers of 2,2,2-trifluoroethyl methacrylate and methyl a-trifluoromethyl acrylate with vinyl ethers. Polym. Degrad. Stab. 2003, 79, 345-351. [CrossRef]

29. Zhou, G.-G.; Chen, J.-G.; Wang, M.-X.; Zhang, M.; Guo, J.-L.; Shen, S.-K.; Liu, Z.-T.; Liu, Z.-W.; Jiang, J.-Q.; Jian, L. Insight into the role of intermolecular interactions on the enhanced solubility of fluorinated epoxide oligomer in supercritical $\mathrm{CO}_{2}$. Green Chem. 2015, 17, 4489-4498. [CrossRef]

30. Moller, E.; Schreiber, U.; Beuermann, S. In line spectroscopic investigation of fluorinated copolymer synthesis in supercritical carbon dioxide. Macromol. Symp. 2010, 289, 52-63. [CrossRef]

31. Schreiber, U.; Hosemann, B.; Beuermann, S. $1 \mathrm{H}, 1 \mathrm{H}, 2 \mathrm{H}, 2 \mathrm{H}-$ Perfluorodecyl-acrylate-containing block copolymers from ARGET ATRP. Macromol. Chem. Phys. 2011, 212, 168-179. [CrossRef]

32. Frisch, M.J.; Trucks, G.W.; Schlegel, H.B.; Scuseria, G.E.; Robb, M.A.; Cheeseman, J.R.; Scalmani, G.; Barone, V.; Mennucci, B.; Petersson, G.A.; et al. Gaussian 09, Revision D.01; Gaussian, Inc.: Wallingford, CT, USA, 2010.

33. Dai, K.; Wang, K.; Li, Y.; Chen, J.-G.; Liu, Z.-W.; Lu, J.; Liu, Z.T. Construction of $\beta$-trifluoromethyl enol ether via base-promoted C-O coupling and rearrangement of hydrogen atom. J. Org. Chem. 2017, 82, 4721-4728. [CrossRef]

34. Yuan, Y.; Teja, A.S. Quantification of specific interactions between $\mathrm{CO}_{2}$ and the carbonyl group in polymers via ATR-FTIR measurements. J. Supercrit. Fluids 2011, 56, 208-212. [CrossRef]

35. Hu, D.; Sun, S.; Yuan, P.-Q.; Zhao, L.; Liu, T. Exploration of $\mathrm{CO}_{2}$-philicity of poly(vinyl acetate-co-alkyl vinyl ether) through molecular modeling and dissolution behavior measurement. J. Phys. Chem. B 2015, 119, 12490-12501. [CrossRef] [PubMed]

36. Siegmann, R.; Drache, M.; Beuermann, S. Propagation rate coefficients for vinylidene fluoride homopolymerizations. Macromolecules 2013, 46, 9507-9514. [CrossRef]

37. Beuermann, S.; Buback, M. Rate coefficients of free-radical polymerization deduced from pulsed laser experiments. Prog. Polym. Sci. 2002, 27, 191-254. [CrossRef]

38. Marien, Y.W.; Van Steenberge, P.H.; Barner-Kowollik, C.; Reyniers, M.F.; Marin, G.B.; D’hooge, D.R. Kinetic Monte Carlo modeling extracts information on chain initiation and termination from complete PLP-SEC traces. Macromolecules 2017, 50, 1371-1385. [CrossRef]

39. Coote, M.L.; Davis, T.P. The mechanism of the propagation step in free-radical copolymerisation. Prog. Polym. Sci. 1999, 24, 1217-1251. [CrossRef]

40. Moscatelli, D.; Dossi, M.; Cavallotti, C.; Storti, G. Ab initio calculation of the propagation kinetics in free radical polymerization: Chain length and penultimate effects. Macromol. Symp. 2007, 259, 337-347. [CrossRef]

(C) 2020 by the authors. Licensee MDPI, Basel, Switzerland. This article is an open access article distributed under the terms and conditions of the Creative Commons Attribution (CC BY) license (http://creativecommons.org/licenses/by/4.0/). 